MATEC Web of Conferences 2, 04001 (2012)

DOI: $10.1051 /$ matecconf $/ 20120204001$

(C) Owned by the authors, published by EDP Sciences, 2012

\title{
Effect of Local Temperature during Service On the Strength of Concrete
}

\author{
M. Merbouh ${ }^{1}$, A Hamouine ${ }^{1}$, I Benoudjafar ${ }^{2}$ \\ ${ }^{1}$ University of Bechar, Department of Civil Engineering, FIMAS Laboratory, Algeria \\ ${ }^{2}$ University of Bechar, Bechar, Algeria
}

\begin{abstract}
The role of local temperatures during service is significant or very significant, considering the safety margins provides for in the design of the structures in hot regions, worsening with severe weather conditions for hardening.

In this context, data on the behaviour of concrete at service temperatures are needed for predicting the safety of buildings in different regions of the world. The present work aims to study the sensitivity of hydraulic concrete in its thermal environment, such as cold regions, moderate and hot. A thermal room was designed to simulate and to stabilize the temperatures of different regions. Using three different compositions, based on local materials with different sands, is shown that the performance of concrete falling from a dramatically with increasing temperature from -15 to $60{ }^{\circ} \mathrm{C}$. The changes in strength are presented, quantified and compared with those obtained in normal temperatures. The impact on the performance and life of structures in these areas are important, which involves the necessity of taking into account the risks caused by geoclimatic conditions in the structural design.

Keywords: Concrete, temperature changes, thermal environment, hot or cold, strength and performance.
\end{abstract}

\section{Introduction}

Availability of materials for concrete has made its universal use and difficult to conquer for economic, technical and aesthetic. Indeed, the concrete structures are still likely to be subjected to thermal actions [1] for functional reasons in areas with severe operating temperatures , typically works undergoing large temperature gradients (change daily and seasonal), accidental (fire, thermal shock). The concrete is still in use for several seasons, at different temperatures. This temperature range is extended upward in regions of warm climate and parallel to the bottom in areas cold. It can be done in situations where concrete is exposed to high temperatures during the summer, sometimes exceeding $55^{\circ} \mathrm{C}$ for Saharan climates (Figure 1), or low temperatures during the night, even negative during the winter.

In this context, our work is essentially experimental main objective is to evaluate the performance of concrete in its thermal environment in hot zones, intermediate and cold, for temperatures ranging from $-15^{\circ}$ to $+60^{\circ} \mathrm{C}$, as the case of most of the regions in. Three common types of concrete have been tested for three different types of sand in the region of Bechar (Algeria). Three different types of sands in the region of Bechar on south west of Algeria. 


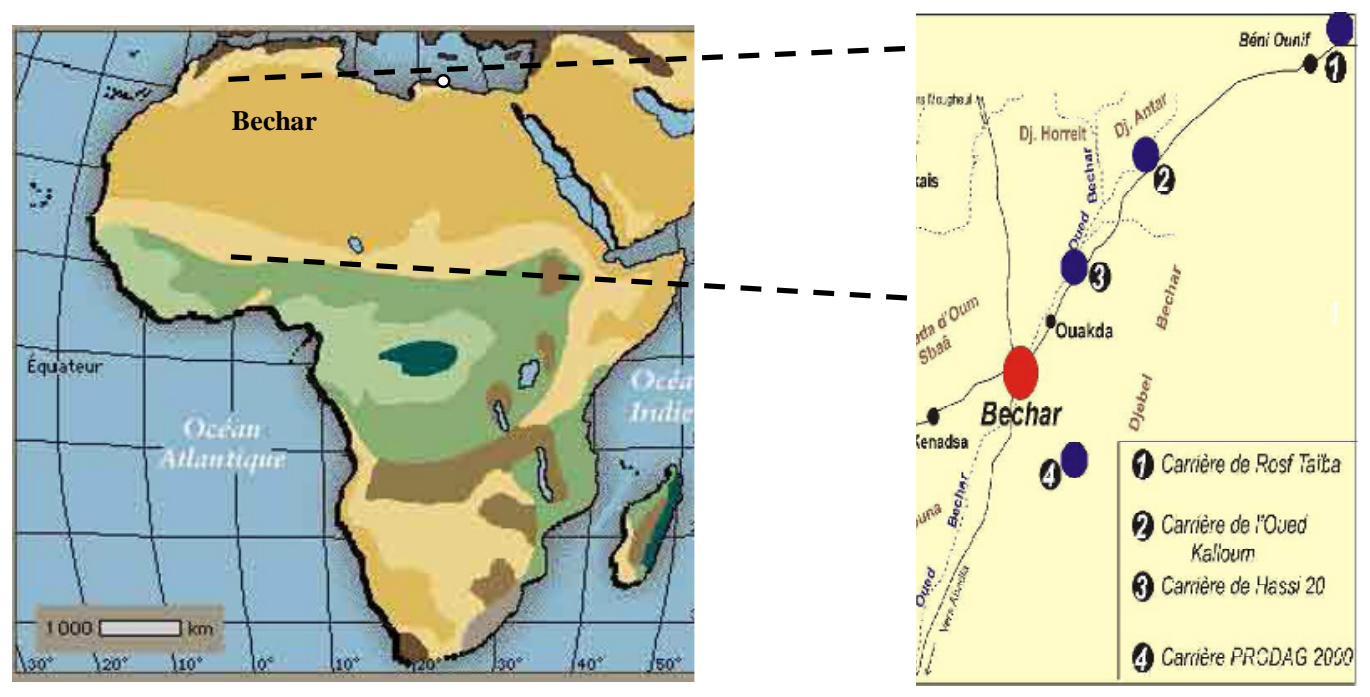

Fig. 1. Hot Areas of Africa and the Middle East

Fig. 2. Careers and Sources of Aggregates

\section{Experimentation}

\subsection{Materials}

Materials used were selected from aggregates the most exploited in the region of Bechar, in south west Algeria, which by its varied geological context [2], and has significant resources for aggregates quarry materials. This motivated us to link between the effect of temperature and use of local aggregates, Figure 2.

- The size analysis showed that all the sands Wadi Kalloum, Hassi 20 and Rosf Taiyeba) have a continuity and a smooth integration of their grading curves in the specified norm (NF P 18-541) Figure 3. In addition, the results of the test sand equivalent values confirmed by methylene blue value, show that the sand of Wadi Kalloum is very clean sand not clay, the Hassi 20 is slightly clay clean only eligible. For cons, the sand Rosf Taiyeba is a sandy loam found not clean. Gravel PRODAG is of good quality and good continuity (Figure 4), with a low water absorption ( $\mathrm{Ab}=$ $0.45 \%)$, good wear resistance in the presence of water $(\mathrm{MDE}=10.62 \%)$ and an acceptable kurtosis $(\mathrm{Ap}=15,50 \%)$.

- The summary chemical analysis performed on the aggregates is confirmed by different authors, who worked on the same materials [3], [2], [4], Table 1: 


\section{INVACO2}

Table 1. Chemical Composition and Characteristics of Sands and Gravel

\begin{tabular}{|c|c|c|c|c|c|c|c|}
\hline & \multicolumn{4}{|c|}{ Chemical Composition Contents } & \multirow{2}{*}{$\begin{array}{c}\text { Blue of } \\
\text { Methylene } \\
\text { Value (VB) }\end{array}$} & \multirow{2}{*}{$\begin{array}{c}\text { SE) } \\
\text { Sand } \\
\text { Equivalent }\end{array}$} & \multirow{2}{*}{ Nature } \\
\hline & Carbonate & Chloride & Sulfates & Insolubles & & & \\
\hline $\mathbf{S}_{\mathbf{K}}$ & $2,20 \%$ & $0,50 \%$ & null & $97,30 \%$ & 0,66 & $95.60 \%$ & $\begin{array}{l}\text { Limestone } \\
\text { very clean }\end{array}$ \\
\hline $\mathbf{S}_{\mathbf{H}}$ & $5,14 \%$ & $0,60 \%$ & trace & $94,26 \%$ & 1,33 & $66.10 \%$ & $\begin{array}{c}\text { Limestone } \\
\text { slightly } \\
\text { clay }\end{array}$ \\
\hline $\mathbf{S}_{\mathbf{R}}$ & $33,08 \%$ & $0,28 \%$ & null & $66,64 \%$ & 1,16 & $36.16 \%$ & $\begin{array}{c}\text { Silica- } \\
\text { Limestone- } \\
\text { Clay } \\
\end{array}$ \\
\hline $\mathbf{G}_{\mathbf{P}}$ & $79.50 \%$ & $0.65 \%$ & trace & $19.85 \%$ & I & / & Limestone \\
\hline
\end{tabular}

$\mathrm{S}_{\mathrm{K}}$ : Sand Wadi Kalloum, $\mathrm{S}_{\mathrm{H}}$ : Sand Hassi $20, \mathrm{~S}_{\mathrm{R}}$ : Sand Rosfa Tayeba, $\mathrm{G}_{\mathrm{P}}$ : Gravel PRODAG.

- For making different types of concrete, the water is drinking water from the dam Djorf Torba. Conform to the specifications of use, NF P18-303.

The cement used is: CPJ-CEM II / A 42.5 (NA 442-200), denoted J, of M'Sila (Algeria), Table 2.

Table 2. Composition of cement $\mathrm{J}$

\begin{tabular}{|c|c|c|c|c|c|c|}
\hline \multicolumn{7}{|c|}{ Chemical Composition (\%) } \\
\hline $\mathrm{Si}-\mathrm{O} 2$ & Al2-O3 & $\mathrm{Fe}-\mathrm{O} 3$ & $\mathrm{Ca}-\mathrm{O}$ & $M g-O$ & $\mathrm{~S}-\mathrm{O} 3$ & $\mathrm{Ca}-\mathrm{O}$ \\
\hline 22 & 5.50 & 4.6 & 65 & 0.98 & 1.80 & 1.8 \\
\hline \multicolumn{7}{|c|}{ Mineralogical composition (\%) } \\
\hline \multicolumn{2}{|c|}{$C 3 S$} & \multicolumn{2}{|c|}{$C 2 S$} & $C 3 A$ & \multicolumn{2}{|c|}{$C 4 A F$} \\
\hline \multicolumn{2}{|r|}{64} & \multicolumn{2}{|c|}{18} & 8 & \multicolumn{2}{|r|}{10} \\
\hline
\end{tabular}

Table 3. Ordinary Concrete Compositions

\begin{tabular}{|c|c|c|c|}
\hline \multirow{2}{*}{$\begin{array}{c}\text { Material } \\
(\mathbf{K g})\end{array}$} & \multicolumn{3}{|c|}{ Compositions $(\mathbf{K g} / \mathbf{m 3})$} \\
\cline { 2 - 4 } & $\begin{array}{c}\mathbf{B O} \\
\left(\mathbf{S}_{\mathbf{K}}-\mathbf{J}\right)\end{array}$ & $\begin{array}{c}\mathbf{B O} \\
\left(\mathbf{S}_{\mathbf{H}}-\mathbf{J}\right)\end{array}$ & $\begin{array}{c}\mathbf{B O} \\
\left(\mathbf{S}_{\mathbf{R}}-\mathbf{J}\right)\end{array}$ \\
\hline $\begin{array}{c}\text { Cement } \text { CPJ } \\
\text { CEM II } 42.5\end{array}$ & 350 & 350 & 350 \\
\hline Gravel $(3 / 8)$ & 1015,8 & 1132,6 & 1010,3 \\
\hline Sand $S_{K}$ & 719 & & \\
\hline Sand $S_{H}$ & & 629,93 & \\
\hline Sand $S_{R}$ & & & 673.95 \\
\hline Water & 227,5 & 217 & 246,75 \\
\hline $\begin{array}{c}\text { Density of } \\
\text { fresh concrete }\end{array}$ & 2312,33 & 2329,5 & 2281 \\
\hline
\end{tabular}




\subsection{Composition of ordinary concretes}

Three formulations used are ordinary $\mathrm{BO}\left(\mathrm{S}_{\mathrm{K}^{-}} \mathrm{J}\right), \mathrm{BO}\left(\mathrm{S}_{\mathrm{H}^{-}} \mathrm{J}\right)$ and $\mathrm{BO}\left(\mathrm{S}_{\mathrm{R}^{-}} \mathrm{J}\right)$, based on crushed sands $\mathrm{S}_{\mathrm{K}}$ : Wadi Kalloum, $S_{H}$ : Hassi 20 and $S_{R}$ : Rosfa Tayeba (Table 3) with the same cement J. In this study we chose to consider the workability of concretes constant and not the W/C. However, the sand Rosfa Tayeba that was used contains $7 \%$ of particles smaller than 80 microns, which increases the need for excessive water W/C was varied of 0,5 to 0,705 .

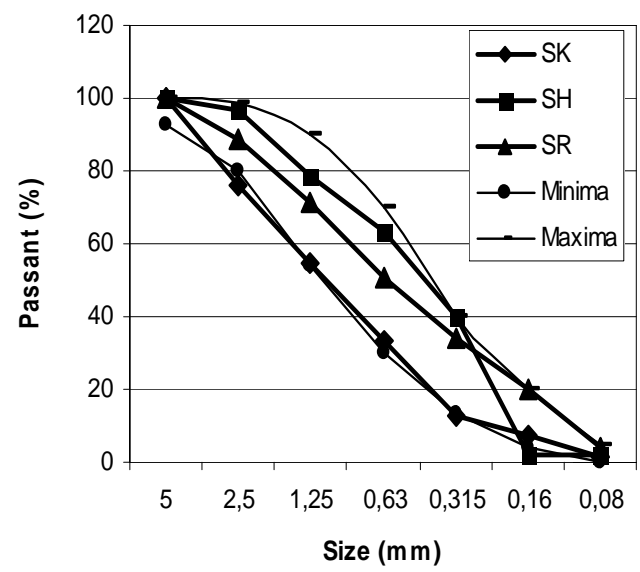

Fig. 2. Gradation of sands

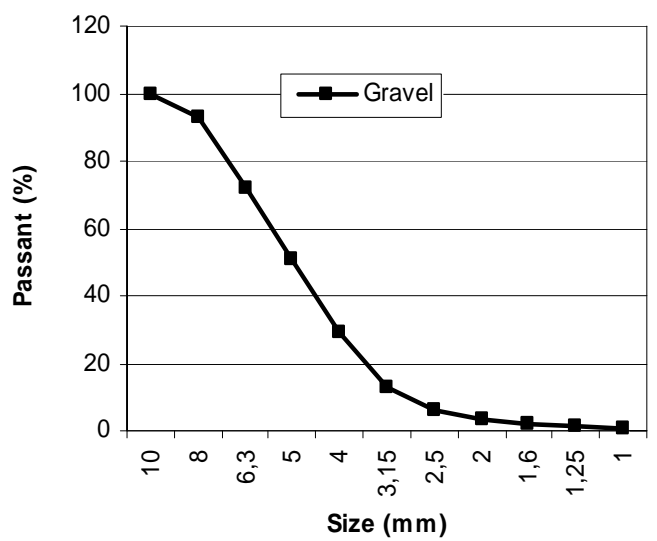

Fig. 3. Gradation of Gravel

\subsection{Design of the thermal enclosure}

It has a thermal chamber adapted to the testing machine to studying concrete strength according to temperature. It stabilizes the temperature within the machine and the specimen under test, Figure 5. a and $\mathrm{b}$. The thermal room covered with aluminium foil is thermally and electrically isolated to protect the machine first, and to limit heat loss. The heating of the enclosure is provided by an adjustable resistor, mounted on a control console.

We used two models of thermometer; shielded thermometer and a digital thermometer, for controlling the stability of programmed des temperatures.

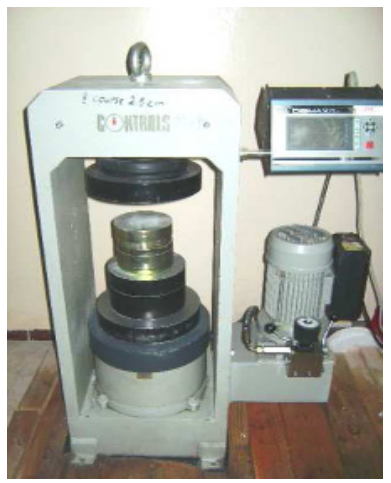

Fig. 5. a- Machine Test

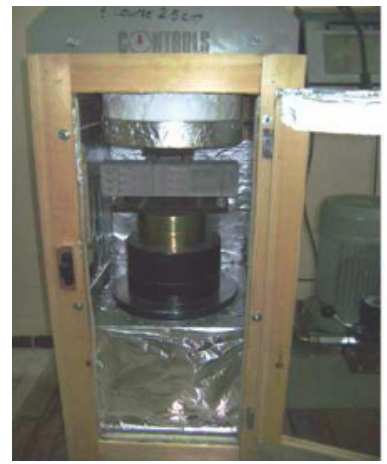

Fig. 5. b- Overview of the Enclosure Mounted Heat 


\subsection{Testing procedures}

To study the behavior of hardened concrete after 28 days, at different temperatures, we carry out tests on specimens (10x10x10 for compressive test and 7x7x28 for tensile test). Six specimens for each level temperature. The average of maximum strength is recorded:

- At cold, the samples have undergone a thermal treatment at low temperatures, a fridge-freezer programmable $-15,-10$ and $0{ }^{\circ} \mathrm{C}$ for 24 hours and then crash immediately.

- At hot, the samples, who underwent a simultaneous thermal conditioning at temperatures average $10^{\circ} \mathrm{C}, 20^{\circ} \mathrm{C}$ and higher temperatures of $30^{\circ} \mathrm{C}$ to $60^{\circ} \mathrm{C}$ for 24 hours, using a programmable oven then the crash.

\section{Results and discussion}

\subsection{Compressive strength}

Evolution of compressive strength of different concretes studied as a function of temperature is shown in Figure 7.

Generally the strength of three concretes decreases with increasing temperature. However, there are three consecutive stages of evolution, separated by temperatures:

$0{ }^{\circ} \mathrm{C}$ : limit for the cold phase (low temperature). And $40{ }^{\circ} \mathrm{C}$ : limit for the more or less moderate phase, from which begins the warm phase (high temperature).

- In the first phase $\left(-15{ }^{\circ} \mathrm{C}\right.$ to $\left.0{ }^{\circ} \mathrm{C}\right)$, the evolution curves of the different concretes is more pronounced, the resistance is much higher than those at normal temperature $20{ }^{\circ} \mathrm{C}$. Freezing increased the strength of concrete by the phenomenon of crystallization [5]. For temperatures between $-15^{\circ} \mathrm{C}$ and $-10{ }^{\circ} \mathrm{C}$ the resistance is between 50 to $60 \mathrm{MPa}$, the composition $\mathrm{BO}\left(\mathrm{S}_{\mathrm{R}}-\mathrm{J}\right)$ gives values slightly higher than those of $\mathrm{BO}\left(\mathrm{S}_{\mathrm{H}^{-}} \mathrm{J}\right)$ and $\mathrm{BO}\left(\mathrm{S}_{\mathrm{K}^{-}} \mathrm{J}\right)$. These resistances are high, but with remarkable ecce fragility in the crash.

- In the second phase, when temperatures are moderate $\left(0\right.$ to $\left.40^{\circ} \mathrm{C}\right), \mathrm{BO}\left(\mathrm{S}_{\mathrm{R}^{-}} \mathrm{J}\right)$ based on the least clean sand and more clay gives the lowest resistance, with a gap of about 5 to $8 \mathrm{MPa}$ compared to concrete made from clean sands $\mathrm{BO}\left(\mathrm{S}_{\mathrm{H}^{-}} \mathrm{J}\right)$ and $\mathrm{BO}\left(\mathrm{S}_{\mathrm{K}^{-}} \mathrm{J}\right)$.

It is found that the temperature $40^{\circ} \mathrm{C}$ has a threshold for acceptable behavior of ordinary concrete studied.

- The third phase $\left(40\right.$ to $60^{\circ} \mathrm{C}$ ) is a phase at risk. The slopes of the curves of the performance of the soundtrack $\mathrm{BO}\left(\mathrm{S}_{\mathrm{H}^{-}} \mathrm{J}\right)$ and $\mathrm{BO}\left(\mathrm{S}_{\mathrm{K}}-\mathrm{J}\right)$ begin to fluctuate with remarkable ductility in the crash, the decline is increasing especially for concrete $\mathrm{BO}\left(\mathrm{S}_{\mathrm{R}}-\mathrm{J}\right)$ where resistance fall in a more dangerous and can reach $20 \mathrm{MPa}$ after $60{ }^{\circ} \mathrm{C}$.

The temperature change produced by a dry climate and desert can alter the behavior of concrete and causes many physical and chemical phenomena that develop on a microscopic scale and result in a macroscopic scale, by a progressive damage of the material and a significant risk of thermal instability [6]. Limestone aggregates have a better thermal behavior at high temperature, for against the existence of silica reduces the resistance (certain forms of silica undergo a dimensional change) [7], [8]. The existence also of clay, because of its nature as an organic material more sensitive to temperature, is additional to this defect. This item can be crystallized and becomes faster than the calcareous elements with temperature. This observation is confirmed by the relatively strong concrete $\mathrm{BO}\left(\mathrm{S}_{\mathrm{R}^{-}} \mathrm{J}\right)$. 


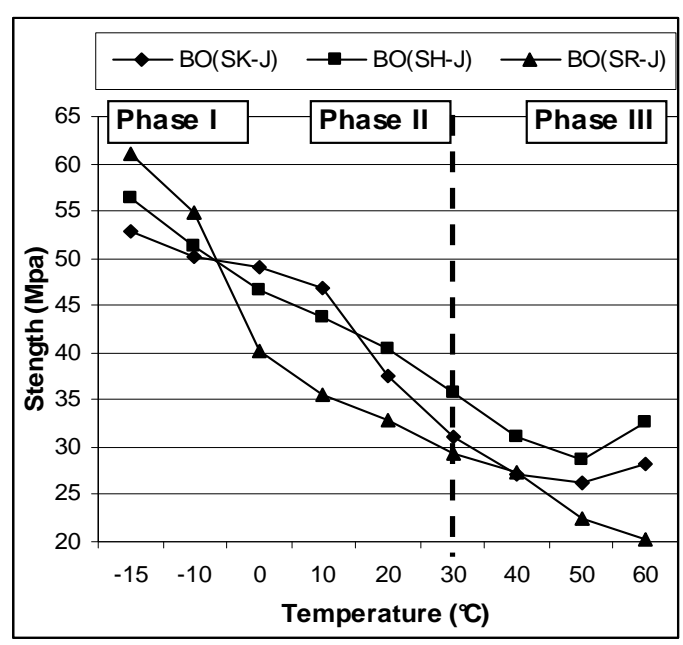

Fig. 7. Evolution of the compressive Strength.

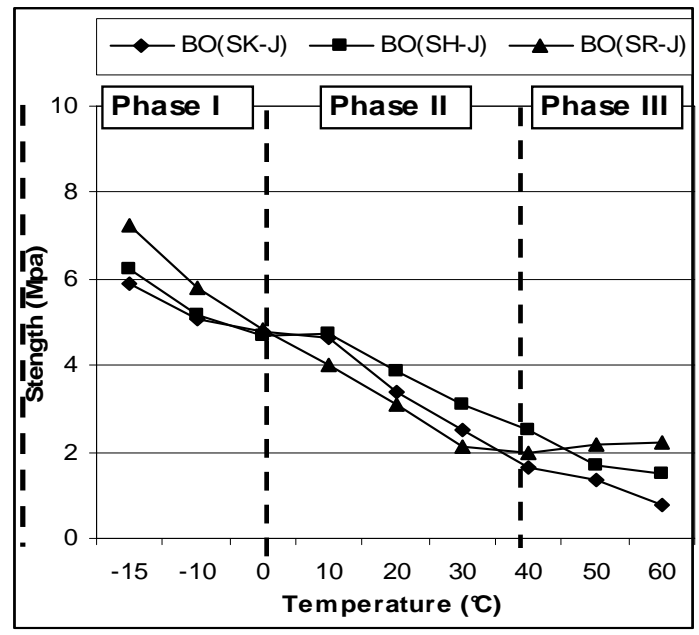

Fig. 8. Evolution of the Tensile Strength.

A comparison of the resistances obtained at different temperatures shows that the phase of low temperature $\left(0\right.$ to $\left.-15^{\circ} \mathrm{C}\right)$ may increase the resistance until nearly double (from 40 to $\left.90 \%\right)$, and this depending on the sand. The difference in stress may vary from a gain of resistance at $0{ }^{\circ}$ for 10 to $30 \%$ to a loss of strength from 20 to $30 \%$ at $40^{\circ} \mathrm{C}$. Beyond $40^{\circ} \mathrm{C}$, the loss is significant with some instability, it can exceed $30 \%$ for $\mathrm{BO}\left(\mathrm{S}_{\mathrm{R}} \mathrm{J}\right)$ at $60^{\circ} \mathrm{C}$. The latter is most sensitive to temperature. The rate of fall in resistance is related to the microstructure of each concrete (sand in our case) which may change different physicochemical leading to the departure of free water and dehydration [9].

\subsection{Tensile strength}

Although the tensile strength of normal concrete is generally low compared to its compressive strength, we also find that the performance of all the concretes studied also decreases with temperature changes (Figure 8). These changes are similar to the case of compression for the first two phases of low and moderate temperatures. The difference is in the third phase when temperatures exceed $40{ }^{\circ} \mathrm{C}$. The high temperatures are more aggressive for concrete based on calcareous sands own $\left(\mathrm{BO}\left(\mathrm{S}_{\mathrm{K}^{-}} \mathrm{J}\right)\right.$ and $\left.\mathrm{BO}\left(\mathrm{S}_{\mathrm{H}^{-}} \mathrm{J}\right)\right)$ for the concrete base of sand-silica-calcareous and clay $\mathrm{BO}\left(\mathrm{S}_{\mathrm{R}}-\mathrm{J}\right)$, which becomes relatively more efficient. This temperature range severely damages the tensile strength of concrete to clean sands (drop from 60 to $70 \%$ ), where the resistance approaches zero for $\mathrm{BO}\left(\mathrm{S}_{\mathrm{K}}-\mathrm{J}\right)$.

\section{Conclusion}

Concrete structures are subjected to significant thermal gradients. Low temperatures $\left(-15 / 0{ }^{\circ} \mathrm{C}\right)$ are not a problem of resistance further that fragility.

However, the high operating temperatures, which prevail during the summer in warm regions, exhibit the performance of ordinary concrete with a very serious challenge.

It is advisable to take into account the severe conditions when sizing, with a careful selection of materials, especially sand.

The compressive strength and drop exceeds the current margins of safety for certain works. It becomes dangerous for concrete based on quartz sand and clay, with a remarkable ductility. 


\section{INVACO2}

Looking ahead, it now seems essential to control the development of in-situ physical and chemical properties of concrete, reflecting the high local temperatures depending on the geo climate conditions, which remains an unknown area.

\section{References}

[1] R. Favre, J.-P Jaccoud, O. Burdet, H. Charif, Dimensionnement des structures en béton, Aptitude au Service et Eléments de Structures, Volume 8, 3ème Edition, Presse Polytechniques et universitaires Romandes, Lausanne, Switzerland (1997).

[2] O.R.G.M, Office National des Gisements Miniers, Livret des substances utiles non métalliques de l'Algérie, édition géologie, Algérie (2000).

[3] P. Deleau, Les Bassins Houillers Sud Oranais dans la région de Colomb Béchar, 2ème Série de la carte géologique de l'Algérie, 2eme série stratigrafique, $\mathrm{n}^{\circ} 20$, Livre I: stratigraphie. In- $4^{\circ}, 278$ p., 91 fig., 18 tabl.,8 pl., 2 cartes h.-t (1951).

[4] SONAREM, Société National des Recherches Minières, Etude hydrogéologique de la région de Béchar, Rapport final inédit (1976).

[5] TRANSPORTATION RESEARCH CIRCULAR E-C107, Control of Cracking in Concrete, State of the Art, Transportation Research Board, Basic Research and Emerging Technologies Related to Concrete committee, October 2006, Transportation Research Board, 500 Fifth Street, NW, Washington, DC 20001, www.TRB.org (2006).

[6] U. Schneider, Behavior of concrete at high temperatures, Report to RILEM Committee, 44-PHT; The Hague 72 (1982).

[7] D. Campbell, P.M. Dessai, The influence of Aggregate on the Behaviour of Concrete at Elevated Temperatures, MENDELEY-free, Nuclear Engineering and Design, 1967. Vol. 6, pp. 65-77 (1967.

[8] R. Felicetti, P.G. Gambarova, On the residual Tensile Properties of High-Performance Siliceous Concrete Exposed to High Temperature, Proc. Int Workshop on "Mechanics of Quasi-Brittle Materials and Structure", Ed. By G. Pijaudier-Cabot, Z. Biinar and B. Gérard, Prague (Czech Rep.), March 1998, pp. 167-186 (1999).

[9] A. Noumowe, Effet des hautes températures sur le béton, Thèse de génie civil, Institut National des Sciences Appliquées de Lyon (1995). 